\title{
Addressing threats: European foreign policy toward the Middle East since the European Security Strategy
}

\author{
Ruth Hanau Santini ${ }^{1}$
}

\begin{abstract}
This paper looks at the qualitative change in the foreign policy discourse by the European Union towards the Middle East, as well as the EU's overall degree of consistency between words and deeds. By looking at European Council Conclusions as well as General Affairs Council conclusions, it will be argued that on a discursive level the Union has taken stock of the emergence of new threats to its security, and has started shifting its attention from state failure and regional conflicts to the threats posed by terrorism and non-conventional proliferation. Secondly, by differentiating among three kinds of coherence, it will be shown that the main source of incoherence in the Union external action in the Middle East is not to be found in its institutional or horizontal dimensions, but in its vertical level, that is between the Union and member states. Examples will be provided in order to substantiate an overall claim: the EU security discourse might have changed; its policies however remain driven by the difficult balancing exercise between Brussels and national capitals.
\end{abstract}

Keywords: EU foreign policy, ESDP, European security strategy, EU-Middle East relations

\footnotetext{
${ }^{1}$ Ruth Hanau Santini is currently completing a PhD at the University of Naples Federico II on the evolution of threat perception among European policymakers since 9/11.
} 


\section{Introduction}

The European Union is actively involved in Middle Eastern politics, suffice it to look at its role within the Quartet, the EU3 vis-à-vis Iran, two ESDP missions in Palestine, one police mission in Iraq and a European military support to the southern Lebanon Unifil mission. This goes without considering humanitarian aid, cooperation and trade agreements. Only for humanitarian aid, in 2006 ECHO's humanitarian assistance to the Middle East represented 1/5 of the total EU world assistance, summing up to EUR 134 million. While in geo-strategic terms, Europe depends for 45\% of its oil supplies from the Middle East, $40 \%$ of which from Opec countries. These brief remarks show the multilayered nature of European interest in the region. The European involvement and engagement in the region responds to different sets of criteria, from reputation to political and geo-economic interests. Focusing on this region, this analysis will examine how security concerns are framed by the EU. The foreign and security policy discourses will by extrapolated by looking at General Affairs Council Conclusions (Gaerc) and at the European Council Presidency Conclusions. While since 9/11 the tone of the discourse towards the challenges posed by this region has shifted, paying greater attention to proliferation and terrorism, pragmatically the Union has failed to devise coherent strategies in these policy areas, due to the difficulty of reaching a sufficient degree of understanding with member states over the long-term strategies to deploy in the area.

Secondly, the EU's foreign policy consistency will be assessed by cross-checking its operational activity in different contexts: in its intra-institutional coordination (institutional coherence), among different policy areas (horizontal coherence) and vis-à-vis member states (vertical coherence). Thirdly, considering the way in which the Union perceives threats to its security and the way it addresses them, a preliminary definition of the kind of actor the EU is in this regional context will be provided in the final section.

\section{How does the EU understand and frame security?}

\subsection{How does Europe speak about the Middle East?}

The Middle East has historically been and still is one of the key areas of European interest. The European Union has stressed several times "the global strategic importance of peace, stability and prosperity in the Mediterranean and the European commitment to the resolution of the Middle East conflict" (European Council, 16-17 June 2005). Its salience is clearly spelled out in the 2003 European Security Strategy, which has been defined as the "most ambitious security and defence initiative since the collapse of the European Defence Community in 1954" (Haine, 2004).

The threats associated to this geo-strategic area are mainly linked to the regional dimension and the risks of de-stabilization of the regional order. The nature of the threats the region poses is diversified and its underdeveloped regional institutionalization has further increased EU risks' perceptions vis-àvis threatening strategic scenarios. In the post-9/11 context, the focus of European foreign policy toward the Middle East has shifted, mainly on the discursive level, where the security discourse has tended to identify terrorism as both an internal European and external threat linked to radical forms of Islam. The Mediterranean, as Volpi notes, from being held as an environment of diffused threats pre9/11 has acquired a sense of new urgency (2007). International terrorism has become the catchword defining the nature of the threat posed by Mediterranean and Middle Eastern radical Islamist groupings. In December 2003, for instance, after the terrorist attacks in Turkey, the European Council Presidency stated that: "The Union reaffirms its determination to defeat terrorism together with others in the 
international community and to provide common response to this global threat" (Council doc, 5381/04, 12-13 December 2003: 15). Even more clearly, this was referred to by the June 2004 European Council Conclusion related to the establishment of the "Strategic Partnership with the Mediterranean and the Middle East", aimed at promoting political reform, stimulating trade and economic cooperation and thirdly combating terrorism, non-proliferation and illegal migration (Council doc, 10679/2/04 REV 2, 17-18 June 2004: 15). The formulation got more explicit in November 2004, when the Council affirmed sharing responsibility with the US "in addressing key threats and challenges, such as regional conflicts, in particular the Middle East; terrorism, proliferation of WMD; AIDS; the fight against poverty /(Council doc, 14292/1/04 REV 1, 4-5 November 2004: 7).

The lenses through which the EU has looked at this region might have changed, identifying new issues threatening its security, on the ground, however, the Union has addressed mainly "old kinds of concerns", namely state building, the reverse of the coin, state failure and regional conflicts.

\subsection{What is the prevailing security understanding in Europe?}

In the realist view of security, states are the main referent objects of security, which is to be gained through power politics and military means (Hyde- Price, 2001:30). Given the anarchic structure of the international realm, the security dilemma constitutes the inescapable determining factor of international life. From the 1970s, however, this view became increasingly challenged from neoliberal institutionalists who, sharing many of the ontological and epistemological realists' assumptions, focused on the chances for cooperation among states, stressed the increasing relevance of non military aspects of power, especially economic, political and societal forms of power (soft), recognised the increasing role of non-state actors in the international system. As a consequence, in the field of security studies, a growing literature started focusing on the non-military dimension of security. This contributed to the shift from strategic to security studies. In the 1980s, a third stream of thought has emerged, critical theory, which has criticized the former two for having merged into a "neo-neo" synthesis (Ruggie, 1986). The assumption for the emergence of this new analytical approach was the demise of the prevailing conception of states as sole repository of the duty and means to grant the inviolability of national borders and the safety within them from outside menaces. The state has come to be seen as, at least to some extent, a passive actor facing an increasingly complex and unpredictable domestic and international environment. Traditional state security instruments (based on deterrence and defence) have become peripheral given that the post-territorial nature of threats has made them not susceptible to military responses. This is so because new threats mostly target societal rather than state actors. Both agents (state or non-state) and targets (state or non-state) of threats have namely undergone a process of change and their unpredictability has henceforth increased. Within this context, critical theory has emphasized the constructed nature of security relations and of threats to security. Secondly, the referent objects have become individuals rather than the state. The concept of security has also changed, stressing its non-military components. Within this strand, the Copenhagen School has underlined the aspect of "threat-construction" by public authorities who present it as "an existential threat" requiring emergency measures (Buzan et al., 1998: 24).

The European Union understanding of the ways in which its external action can best address and respond to security threats in the Middle East does not fall neatly into just one of these categories, but can be thought of comprising a varying combination of elements from the second ("soft power") and third ( "human security") approach. In a restrictive reading of the second approach, the Union can be 
seen as pursuing "milieu goals" rather than "possession goals" (Wolfers, 1962).

In Wolfers' words, milieu goals "aim at shaping conditions beyond their national boundaries", best exemplified by those efforts aimed at promoting international law or establishing international organizations. The EU, in other words, tries to portray itself as a threefold "normative" agent in world affairs: as a 'moderator of international conflicts' through its support of multilateralism, as a promoter of development in the poorest countries and as an advocate of human rights (Barros-Garcia, 2007: 7). A second aspect of this normative dimension of foreign policy is the way in which instruments are deployed, within a continuum between persuasion, promising rewards, menacing retaliation and threatening the use of force (Holsti 1995). Further distinguishing, one could devise concrete manifestations of "soft" methods - joint ownership, engagement, persuasion and cooperation- and of "coercive" ones - conditionality, sanctions and military action - (Tocci, forthcoming 2007). An approach based on human security would consider the well being of individuals as an overriding concern compared to state security traditional concerns. Within this conception, the dimension of values rather than that of even indirectly EU-security related needs (like stability in the near abroad) would play a central role. This dimension occasionally resurfaces: the focus is on European global "responsibilities", in terms of transforming the international system into a more democratic order.

\subsection{The European Security Strategy: a pendulum swinging closer to soft than to human security}

The European Security Strategy (ESS) is currently taken as reference point by EU institutions as far as the definition of the European security environment and the nature of threats are concerned. Through this document and a series of linked CFSP strategies (the coetaneous WMD strategy, the counterterrorism strategy), the EU gave voice to its ambition to develop its security role from a passive -as provider of economic integration- to a pro-active one.

While it is widely acknowledged that a common outlook on threats and security questions at the EU level is still a far-off perspective (Ekengren, 2006), the ESS marked a qualitative step in this direction. Until 2002, namely, the EU was in short supply of a clear typology of threats, as there was no conceptual consensus on either the content, forms or agents of the threats posed (Kirchner and Sperling, 2002). This depended partially from EU internal dynamics and the slow path of institutionalization in the Common Foreign and Security Policy, but it was also a reflection of a global trend. Prior to the end of the cold war and to a large extent until 11 September, security threats have been mainly looked at through the prisms of interstate violence. Security was scarcely a contested concept, and its prevailing understanding (with the exception of the understanding espoused by the $\mathrm{UN}$ ) reflected the predominance of realist and neorealist IR security approaches.

The ESS then, taking stock of the state of the art of the debates within the security academic community, refers to human security challenges on a world scale, such as poverty and pandemics (ESS, 2003: 5-6) alongside the strategically qualitatively different "key threats" (terrorism, non-conventional weapons proliferation). The ESS has securitized all threats included in its analysis, from the old ones regional crises, organized crime, failed states - to the new ones - international terrorism and WMD proliferation -. The old threats have been "securitized" as they have been attributed a direct impact upon the international order and thought to be facilitating conditions for new threats to emerge, mutually reinforcing one another.

On the other hand, human security challenges failed to receive a strategic priority in the ESS, although they were mentioned in subsequent declarations and speeches by the High Representative: examples 
were either framed in general terms mentioning local grievances and poverty (interview, Euronews, 1 July 2003) or in more specific contexts, such as related to Darfur, which was depicted as "the first war we are aware of being caused by climate change" (Solana, March 2007).

The ESS remains however far from representing a clear and comprehensive strategic outlook for the EU, and this for several reasons. Firstly, it cannot be considered a fully-fledged strategic document, as it does not provide a defined hierarchy among the different threats, something on which neither the Policy Unit nor member states were able to agree. Secondly, it fails to sketch out a geo-strategic European conception distinguishing challenges from threats as they manifest themselves in different geographical areas. Thirdly, while subsequent documents were meant to complement the Strategy, it was never explicitly mentioned that the document itself would undergo the necessary updates and revisions. This implies that the document was at best seen as a snapshot capturing the state of the art of a political outside-the-Union reality as well as inside-the-Union toolbox to efficiently interact with that reality, but without setting out a longer time horizon for EU action.

\section{Assessing the coherence of European foreign policy in the Middle East}

Given the novel nature of one group of dangers and their ranking in the ESS, it could be easy to overstate their relevance in relative terms vis-à-vis traditional threats. Caution, however, pushes us to look for the implementation side in order to check whether, as Jean-Yves Haine notes, despite 11 September and the terrorist attacks on European soil, so-called "old" threats have remained more prominent than new ones (in S. Biscop, forthcoming 2007). Namely, while the EU discourse toward the Middle East has been consistent with that assessment, on the policy level the EU has shown a considerable degree of inconsistencies in its approach toward the Middle East. This could be best thought of on three levels, in terms if institutional, horizontal and vertical consistency (Nuttall in Hill and Smith, 2005).

Reaching vertical consistency, i.e. between the EU foreign policy and those of member states, possibly remains the most visible challenge for the EU in the conduct of its external affairs. Horizontal coherence is reached when different EU policy areas are conducted according to the same logic. Lastly, the coherence between the Community integrationist logic and the second pillar intergovernmental one represents institutional coherence.

\subsection{Institutional coherence}

The Treaty of the European Union introduced a 'single institutional framework' purportedly designed to safeguard consistency in the EU's external action (Art. 3 and Art. 11). A coordination reflex between institutions, through the harmonization of CFSP common positions, strategies and joint actions with the Commission's external action policies should have developed. The appointment of a High Representative for the CFSP, agreed at Amsterdam, complicated this process, as a previously obscure institutional discrepancy became a personal duel between the HR and the External Relations Commissioner.

Considering the Israeli-Palestinian conflict, the two institutional logics at play have failed to go hand in hand. On the one hand, the High Representative -representing the EU within the Quartet, uniting the US, the UN and Russia as a sort of intensified 'contact group' dealing with this regional crisis- was an initiator and promoter of the Roadmap since 2002, on the other, the 2004 Commission's ENP Action 
Plans with Israel and the Palestinian Authority did not envisage any clear institutional link between the progress and respect of the conditions set by the Roadmap and the fulfilment of the political/economic agreements.

For the first time, in June 2002, President Bush called for an independent Palestinian state, living peacefully side by side with Israel. In 2003, in exchange for statehood and the end to settlement activity in the Gaza Strip and the West Bank, the Roadmap required the Palestinian Authority to undertake democratic reforms and fight terrorist attacks against Israel. However, the lack of monitoring and enforcing mechanisms with regard to Israeli settlements' dismantling meant that the only party expected to deliver was the Palestinian Authority. Something similar had already happened: at the Berlin EU Council 24-25 March 1999, the Union had endorsed the two-state solution, without however taking strong stances against Israel's human rights violations and land annexation. While this fallacy was not attributable uniquely to the EU, but to the Quartet, by having associated itself with its proceedings Brussels partly lost some of its appeal in Arab capitals as well as among Palestinians. The two Action Plans' overall stated objective was reaching a comprehensive settlement of the Middle East conflict. However, their leverage vis-à-vis the implementation of the Roadmap was strikingly weak, as no explicit linkage or conditionality clauses were enclosed in the deals. The Plans' shortcomings have become manifest: in the Action Plan with Israel, critical stances taken by the Commission in its previous Report were watered down and references to human rights abuses or international law were barely mentioned. In the Action Plan with the PA, the EU focus was kept more on financial accountability matters than human rights issues or the need for an effective separation between executive and legislative powers (Del Sarto 2007: 34-37). Both cases hence point to a structural EU deficit insofar as economic, political and diplomatic means have been deployed within a short-term perspective and without making use of the synergies their inter-linkages could provide.

\subsection{Horizontal coherence}

In June 2000, the Council adopted a Common Strategy on the Mediterranean Region, which was renewed until January 2006. This strategy involved all the Barcelona process countries plus Libya and was aimed at strengthening the political and economic relations of the EU with this bloc.

In June 2004, the Council endorsed "The Strategic Partnership with the Mediterranean and the Middle East", aimed at promoting the development of a common zone of peace, prosperity and progress in the Mediterranean and Middle East. Politically this was intended to foster good governance, democracy and human rights. Economically, the long-term purpose was to stimulate liberalization reforms and finally, on the security level, measures against terrorism, proliferation and illegal immigration were equally endorsed (Council doc, 10679/2/04 REV 2, 17-18 June 2004: 15). With its adoption, part of the targets spelled out in the 2000 Strategy was upgraded and became more specific: conflict prevention and non-proliferation, aiming at creating a WMD-free Middle East. This followed a December 2003 request by the Council to the Presidency -jointly with the Commission- to come up with concrete proposals embodying the principles endorsed by the European Security Strategy in relation to the Middle East. The framework was to be reviewed every six months and the areas it included were broadened. Terrorism entered as the top priority, together with WMD proliferation. The biggest obstacles in implementing the EU strategies were and remain twofold: strategic interests of individual Member States (i.e. French obstructive stance on Syria) and scarce co-ordination between single Member States and EU bodies, as is the case regarding the listing of terrorist organizations and managing states failures in the region. 


\section{a) - Failing states}

The EU has so far deployed three CFSP missions in the region without providing an overall strategy for state failures' prevention or management: the EU Border Assistance Mission at Rafah (EU BAM Rafah), the EU Police Mission in the Palestinian territories (EUPOL COPPS) and the EU Mission for Iraq (EUJUST LEX).

After the Quartet-brokered Israeli-Palestinian "Agreement on Movement and Access", the first CFSP mission was established in Rafah, at the Gaza-Egypt border in November 2005. The mission aimed at facilitating the opening of the passage while training Palestinian personnel working at the border. Politically, it was meant as a confidence building measure between Israel and the Palestinian Authority. The mission, notwithstanding its limited scope in terms of financial resources and forces on the ground, was considered symbolically important for two reasons: firstly, the Palestinians were granted the only safe passage to get out of the territories, at the same time acquiring a typical feature of state sovereignty, and Israel could partly de-escalate the pressure on the Gaza-Egypt border. Secondly, the EU presence was accepted by both parties, representing a common ground for further co-operation. Leaving the symbolic dimension aside, the EU failed, in concrete terms, to be able to grant the continuing opening of the passage, which was allowed to operate for only $40 \%$ of the time. Both European and Palestinian observers had namely to adapt to Israeli security concerns whose definition has often been arbitrary.

The EU is also present in the Palestinian territories with a Police Mission undertaken at the beginning of 2006, following a request from the Palestinian Authority, for a three-year period. This operation was conceived as a tool supporting the Roadmap's institution building purpose, by consolidating the existing Palestinian security framework. In addition to strengthening the Palestinian civilian police, its task is coordinating EU donors contributing to the upgrading of the existing police force. It is a small mission, consisting of only thirty people on the ground, and since May 2006, in order to avoid being seen as supporting the re-shaping of the security services under a Hamas-led government, it has almost ceased to work.

Beyond individual Member States' engagement in the broader Middle East, since July 2005, the EU arranged a Rule of Law mission in Iraq. The EU's commitment is to train almost 800 Iraqi officials in the criminal justice system. This was agreed by the Troika, composed under the Luxembourg Presidency in cooperation with the External Relation Commissioner and the former British foreign minister, Jack Straw, as representative of the upcoming British Presidency in 2005.

Finally, in the run-up to the escalation of the war between Israel and the Hizbollah in summer 2006, some European countries - France, Italy and Spain whom enjoy strong economic and historical ties to the region - quickly agreed to upgrade the already on the ground but small UN mission. These countries responded to the UN General Secretary's request of 15000 international troops to reinforce Unifil. After the approval of UNSC resolution 1701, Europe pledged a total of 6000 troops, mainly Italian and French. The deployment of an ESDP mission, however, remains politically and organisationally highly problematic as it would be directly linked to the Israeli-Palestinian conflict and the fight against terrorism in the region. In Lebanon, as elsewhere (Afghanistan) the EU still lacks an overall strategy for state failure' prevention and management.

In December 2003, Iraq was depicted as a state at risk of failing, and it was re-affirmed that its stability was in the enlightened interest of all parties involved. 
"The European Council reaffirms that the stability of Iraq is a shared interest and reiterates the Union's commitment to supporting the political as well as economic reconstruction of the country, within the framework of the relevant UNSC Resolution”. (Council doc 5381/04, 12/13 December 2003: 14).

The EU stressed both the regional and the global aspects of the risks posed by the lack of stability and of substantial progress in the country's economic reconstruction.

In June 2004, in view of the restoration of Iraqi sovereignty at the end of the month, Europe was hoping for an increase of the regional stability, and in the establishment of a full cooperation between the Iraqi authorities, the regional powers and the international community.

"The EU affirms its objective of a secure, stable, unified, prosperous and democratic Iraq that will make a positive contribution to the stability of the region; an Iraq that will work constructively with its neighbours and with the international community to meet shared challenges" (Council doc, 10679/02/04 REV 2, 17/18 June 2004: 22).

In the Commission Communication "The EU and Iraq", five areas of engagement are identified where the involvement of the EU could benefit the country. The plan encompasses technical and economic assistance, favouring multilateral cooperation (between Iraqi authorities and the UN), enhancing the EU representation in the country, beginning a process of dialogue on the political level and finally engaging in a diplomatic regional effort to win Iraq's neighbouring countries over in their support for the stabilization of the country. No reference is made either to WMD or to terrorist cells within the country, let alone to neighbouring countries who might exploit the ongoing instability to enhance their relative power position vis-à-vis other Middle Eastern states. Iraq, despite the desire to define a "comprehensive approach" is looked at in isolation from the power struggles going on in the region. Also, any reference to the inter-connectedness nature of old and new threats is absent. Failing states or regional crises are considered by the ESS as dangerous as newer threats as they can be used for further de-stabilizing the political context, by providing a safe heaven for terrorist planning activist or proliferation efforts. In November 2004, with the internal security situation in Iraq steadily deteriorating, the EU verbally condemns terrorist attacks but does not analyse their origin, raison d'être or effective ways to address them. It does, however, start planning a Police and Rule of Law mission in Iraq, other than providing a comprehensive package of assistance.

\section{b) - Fight against terrorism}

In December 2003, the fight against terrorism was seen in optimistic terms, as a bet to be won but one which, given its global inter-connectedness, required a global approach. This optimism seems to draw on member states' national experiences in fighting terrorist groupings in the 1970s-1980s and their mixed successes (success in Germany and the UK, less in Spain and uncertain current developments in Italy). In this depiction, terrorism failed to be analysed and scrutinized in its different geographical expressions, and the stress was more on the EU side to strengthen its international partnerships in this endeavour.

In December 2004, after the Madrid bombings, the internal dimension of the fight against terrorism was substantiated by a series of extensive provisions concerning border security, intelligence, the financial aspect of terrorist networks, civil protection, and by creating counter-terrorism clauses in agreements with third countries. In this Presidency Conclusion, all other threats are considered "key concerns" as the terrorist one is the strategic priority for the EU (Council doc, 16238/1/04 REV 1, 16/17 December 2004: 8-11). 
In response to the coordination needs emerged after the London and Madrid bombings, in December 2005 the EU launched its Strategy on Counter-Terrorism, a cross-cutting task between CFSP and cooperation in Justice and Home Affairs. Despite the Strategy, however, no consistent EU policy towards terrorist organizations has developed yet.

In mid-December 2006, the European Court of First Instance ruled against previous EU decisions to enlist the People's Mujahidin of Iran, considered a terrorist-supporting organisation. This ruling could have a domino effect, for example, in supporting the case for the suspension of the current sanctions against Hamas. Were this to happen, it would point to inconsistent policies conducted by EU institutions. Different national evaluations have brought to paradoxical results: while the Palestinian Hamas movement was listed as a terrorist organization in 2003, the EU - despite US pressures- has avoided attributing the same label to the Lebanese Hezbollah. The decision not to list the group signalled a divergence in views between Member States and the High Representative of CFSP, who lined up with the US in calling for having the Hezbollah defined as a terrorist organization. Had the EU listed the Hezbollah, an overall economic embargo would have been imposed, implying a complete freeze in any trade transaction or even humanitarian programs. This is what happened to the Palestinian government after the electoral victory of Hamas. Following the formation of a Hamas-led government in May 2006, the European Commission suspended political contacts and cooperation with the Palestinian Authority, pending their renewal on Hamas' acceptance of the Quartet's principles. Taking into account the catastrophic humanitarian situation in the Palestinian territories, however, a temporary aid mechanism (TIM) was set in place under the supervision of the World Bank. This mechanism bypasses the institutions-level and directly supports civilian infrastructures. The damage the EU has self-inflicted is threefold. Firstly, differentiating between the Hamas and the Hezbollah without the Council giving an explanation for listing one and not the other has diminished the credibility of the European threat assessment's consistency. Secondly, expressing two views on the same matter, one from the Presidency and one from the High Representative, the EU has increased the aura of ambiguity surrounding its decisions. Thirdly, and most gravely, by having boycotted a democratically elected government, the EU has emptied some of its legitimacy reservoir in the Arab streets.

c) - Non-proliferation policy

The EU Strategy against Proliferation of Weapons of Mass Destruction (WMD) was endorsed by the European Council in December 2003. However, European efforts' still limited impact in the region's WMD policies was recently exemplified in the case of Iran. Despite having tried to impose itself as an indispensable international facilitator in the Iranian nuclear crisis through the EU3 (France, Germany, Great Britain, and since summer 2006, the High Representative for CFSP), the Union has failed to live up to the expectations arisen by the Strategy. This is also linked to the use of Directoires as the EU3, which enjoy more flexibility during negotiations, but are of limited value when final decisions concerning sanctions or the freeze of aid have to be taken at unanimity. On top of that, some countries, such as Italy, Spain, and the Czech Republic question the whole principle of the directoires - partly from self-interest and partly for 'communautaire' reasons. This implies that certain groups of smaller countries may drift apart from discussions on non-proliferation in the CFSP. There is also a clear split between big and small countries; the latter suffering from under-representation during these politically highly delicate negotiations.

In June 2004, the Union expressed its desire to cooperate more fully with Iran, making clear its "concerns": the nuclear programme, the existence of a terrorist threat, the lack of respect for human 
rights and the opposition of Iran to any step in the direction of solving the Israeli-Palestinian conflict. Few months later, in the November Presidency Conclusions, all of these issues are dropped (but they are re-affirmed in June 2005), with the notable exception of the nuclear dossier.

In mid-June 2006, the EU-3 plus 3 (France, UK and Germany with the UNSC members of China, Russia and US) formulated a proposal in Vienna offering Teheran cooperation in the civilian development of nuclear energy in exchange of ceasing the enrichment process of uranium. At that point in time, the EU was confident that chances were good to strike a deal with the Iranian negotiating team headed by Larijani.

At the end of the year, the tone in the EU changed and Iran is called to behave responsibly within the region.

"The European Council expresses its concern about the negative impact of Iranian policies on stability and security in the Middle East. the European Council underlines that Iran needs to play a responsible role in the region" (Council doc, 15914/1/05, 14-15 December 2006: 25).

The leadership had rejected the Vienna proposal and the EU was left with no other tangible option in sight. For the first time, the EU clearly chose a threatening stance suggesting the possibility of adopting sanctions within the UN framework.

"In the absence of action by Iran to meet its obligations, the European Council supports work in the Security Council towards the adoption of measures under Article 41 of Chapter VII of the UN Charter" (ibid).

On the Commission's side, as there have never been cooperation agreements with Iran, action plans or other forms of economic partnership, one can only look at what the Commission has done with the only nuclear power of the region it has a contractual relation with, namely Israel. In the EU-Israel Action Plan both sides agreed to 'further develop co-operation and co-ordination in the prevention of and fight against the illicit trafficking of WMD-related materials' and to co-operate on the development of 'effective systems of national export control, controlling export and transit of WMD-related goods, including WMD end-use control of dual use technologies and effective sanctions for breaches of export control'. While the aim of controlling the trafficking and transit of WMD and related goods should not be a major point of controversy, it is certainly surprising that the ENP-Action Plan explicitly refers to WMD non-proliferation - considering Israel's traditional ambiguity with regards to its nonconventional capabilities and its long-standing reluctance to discuss the matter with other parties. The devil, however, is in the detail. In fact, the Action Plan at no point defines which WMD both sides intend to talk about. More importantly, the Action-Plan states that the WMD dialogue shall be based on two documents, which, however, were not enclosed in the Plan. While the EU WMD Strategy of December 2003 is available, 'Israel's vision on the long-term goals of regional security and arms control process in the Middle East' of 1992 is not easily retrievable.

\section{d)-Regional conflicts: $M E P P$}

In December 2003, the Middle East conflict was framed as an old kind of threat, endangering regional and global stability, whose solution would rely on the creation of a viable Palestinian state and assuring the borders' security of Israel, two typically Westphalian attributes of national sovereignty. The situation on the ground however differed from European expectations and proved to be a difficult case for testing a skilful use of the horizontal toolbox the EU had at its disposal. The two ESDP missions in the Palestinian occupied territories were formally meant to support institution building, but they became useless instruments when the unborn Palestinian state risked failing before having seen the 
light. By "urging" the Palestinian Prime Minister to re-organise the security services and to eliminate the terrorist menace operating in its territory acting against Jerusalem, the EU was formulating the expectation that the PA could act as a state. Towards Israel, the Council expressed its disapproval of the continuing building of settlements as well as later of the security fence. What lacked in this respect, however, were either carrots or sticks attached to it.

In March 2004, the tone of the EU vis-à-vis Israel was embittered and critical of the use of extrajudicial killings (the recent murder of Hamas leader Yassin being the last of a series). With regard to Israeli disengagement plans from the Gaza Strip, Brussels "noted" them, reminding however of the Roadmap framework as the only legitimate one.

A few months later, in June, the EU softly changes tone with Israel, "welcoming" its disengagement from Gaza as a first step of a "complete withdrawal". While Israel was called to comply with international law, accepting its membership within a legalistic international community; the PA was expected to crack down on terrorist activities, with no reference to legal tools or to potential side effects to civil liberties and the rule of law, overarching features of the Commission's external activity. Then, despite "welcoming" regional peace initiatives, the EU remained cool at the idea of setting up joint peace efforts with Middle Eastern countries. This case could point to the structural limit for the ESS' call for efficient multilateralism.

Moreover, the fact that the EU still tends to portray the Israeli-Palestinian issue in isolation from the ongoing frozen and less frozen tensions (Israel-Syria; Lebanon-Syria) shows the lack of clear understanding of the inter-linkages not just between old and new threats (let alone between old challenges and threats) but even more dangerously of those among the several Middle Eastern dossiers (see Council doc, 10679/2/04 REV 2, 17-18 June 2004: 25).

\subsection{Vertical coherence}

For obvious reasons, discrepancies in this domain get an ample media coverage, thereby overdrawing positions which often do not differ in the substance, but for domestic reasons are articulated differently from official EU stances.

The June 2006 Communication from the Commission, "Europe in the world", underlined the necessity for the EU to establish closer relations among all the actors involved in external policies, especially the Union and national capitals. In the first place, the existence and role of the Quartet or the EU3 would gain visibility and legitimacy if all Member States were to actively support it.

The panoply of recent European initiatives towards the Middle East has impaired their overall efficiency: to make one example, in December 2006, Chancellor Merkel announced her will to revitalize the Quartet during the German EU and G-8 Presidency in 2007. This intention had found only verbally the support of the US administration, whose Secretary of State Condoleeza Rice dealt with the crisis in a trilateral way, meeting with Israeli PM Olmert and Palestinian PM Abbas in February 2007 without engaging the European counter-party.

Previously, in November 2006, Spain, Italy and France had declared their intention to promote a regional conference to promote a new peace effort on the Israeli-Palestinian front, which has remained an idea that continues to be floating around. Despite Spain's prime minister, José Luis Zapatero, wish to have England and Germany on board, the two countries have so far been sitting on the fence, 
abstaining from a clear commitment, fearing to create discontent in Jerusalem. According to another proposal put forward by Spain and France -with Italy retreating to a more cautious "wait and see" position-, any attempt to renew the political process should start with five steps: an immediate ceasefire from both sides (which until present was never formally reached); the formation of an internationally acknowledged Palestinian national unity government (which was eventually agreed on in mid-March 2007) ; an exchange of prisoners (PM Abbas promised setting free caporal Shalit but could not deliver); talks between Israel's Prime Minister and his Palestinian counterpart (currently underway despite the lack of recognition by Israel of the new coalition government) and an international mission in Gaza monitoring the cease-fire. Regularly, some national capitals advance a proposal to foster stabilization in the region, be it a regional peace conference, a multi-national force to be sent to the Gaza Strip (an idea floated by Italian Foreign Minister D'Alema in 2006) or formulating various and un-coordinated attempts to get Syria involved in resolving its Golan and Sheba dispute with Israel so as to weaken Iran's relative weight.

\section{Conclusion}

When one looks at official discourses and actual policy implementation, it is often the case that discrepancies emerge. In the case of European foreign policy toward the Middle East, however, the inconsistencies are more between European institutions and single member states foreign policy interests and legacies, than between the security discourse and the policies on the ground conducted by the EU3, the Quartet. Both in words and deeds, namely, the EU espouses an approach towards the Middle East based on multilateralism, that is strong coordination with the UN, which tries to be effective by adopting a multilayered approach, tackling different dossiers with different instruments by its institutions and which has the ambition of putting its efforts into context. It remains to be said, however, that while the discourse has, at least to some extent, evolved including more and more counter-terrorism elements in declarations and agreements with those countries, the EU still tends to intervene when old conflicts and old kinds of threat risk to damage the overall regional balance of power. Then, how it intervenes depends on some internal variables, which have here been looked at horizontal and institutional coordination- for which the room for improvement remains significant, as well as external variables -the regional context in which it operates, other global players- which the EU has so far failed to influence to a relevant degree.

The lack of effectiveness of the overall strategy is hence due to its scarce support by member states when brave and creative initiatives should be undertaken, and by the timidity of EU actions vis-à-vis other global players. 


\section{Bibliography}

X. Barros-Garcia, "Effective Multilateralism and the EU as military power: the worldview of Javier Solana”, EUI Working Paper, RSCAS 2007/2008.

F. Bicchi; M. Martin, “Talking tough or talking together? European security discourses towards the Mediterranean", Mediterranean Politics, vol. 11, No. 2, July 2006.

S. Biscop, The European Security Strategy, Implementing a distinctive approach to security, Ashgate, 2005.

Centro Internacionale Toledo, "EU Civil missions in the Palestinian territories: frustrated reform and suspended security", CITpax Middle East Special Report, N. 1, Summer 2006.

A. De Soto, "End of Mission Report”, The Guardian documents, 12 June 2007.

R. Del Sarto, 'Benchmarking Human Rights and Democratic Development in the Euro-Mediterranean Context: Conceptualising Ends, Means, and Strategies', EuroMeSCo Report, Lisbon: Instituto de Estudos Estratégicos e Internacionais (IEEI), 2007 (forthcoming).

M. Ekengren, "New Security challenges and the need for new forms of EU cooperation: the solidarity declaration against terrorism and the open method of coordination”, European Security, vol. 15, No. 1, 2006.

H. Gärtner, A. Hyde-Price, E. Reiter, Europe's new security challenges, Lynne Rienner Publishers, N.Y., 2001.J-Y. Haine, "Idealism and Power: The New EU Security Strategy", Current History, March 2004.

J-Y. Haine, "The European Security Strategy and threats: is Europe secure", in S. Biscop and J. Andersson, forthcoming 2007.

S. Nuttall, "Coherence and Consistency", in C. Hill and M. Smith, International relations and the 
European Union, Oxford University Press, 2005.

E. J. Kirchner, “The Challenge of European Union Security Governance”, Journal of Common Market Studies, vol. 44, No. 5, 2006.

E. J. Kirchner, J. Sperling, "The new security threats in Europe: theory and evidence", European Foreign Affairs Review, 7, 2002.

F. Volpi, "Introduction: Strategies for Regional Cooperation in the Mediterranean: Rethinking the Parameters of the Debate", Mediterranean Politics, vol. 11, No. 2, July 2006.

M. Webber, S. Croft, J. Howorth, T. Terriff and E. Krahmann, "The governance of European security", Review of International Studies, 30, 2004.

European Union Council Presidency Conclusions:

Council doc, 5381/04, 12-13 December 2003

Council doc, 10679/2/04 REV 2, 17-18 June 2004

Council doc, 14292/1/04 REV 1, 4-5 November 2004

Council doc, 16238/1/04 REV 1, 16-17 December 2004

Council doc, 15914/1/05 REV 1, 15-16 December 2005 